\title{
The effects of Matricaria chamomilla L. hydroalcoholic extract on atherosclerotic plaques, antioxidant activity, lipid profile and inflammatory indicators in rats
}

\author{
Shahin Nargesi ${ }^{1 \oplus \#}$, Ardeshir Moayeri $^{2 \oplus}$, Ayub Ghorbani $^{3 \oplus}$, Yaser Seifinejad $^{4 \oplus}{ }^{\circledR}$ Ehsan Shirzadpour ${ }^{5}{ }^{\circledR}$, \\ Mansour Amraei ${ }^{3}, *(1)$
}

\#These authors contributed equally to this work

${ }^{I}$ Department of Public Health, Faculty of Health, Ilam University of Medical Sciences, Ilam, Iran

${ }^{2}$ Department of Anatomy, Faculty of Medicine, Ilam University of Medical Sciences, Ilam, Iran

${ }^{3}$ Department of Physiology, Faculty of Medicine, Ilam University of Medical Sciences, Ilam, Iran

${ }^{4}$ Biotechnology and Medicinal Plants Research Center, Ilam University of Medical Sciences, Ilam, Iran

${ }^{5}$ Department of Biochemistry, Faculty of Medicine, Ilam University of Medical Sciences, Ilam, Iran

\section{Correspondence}

Mansour Amraei, Department of Physiology, Faculty of Medicine, Ilam University of Medical Sciences, Ilam, Iran

Email: amraei-m@medilam.ac.ir

\section{History}

- Received: 22 May 2018

- Accepted: 09 October 2018

- Published: 24 October 2018

DOI :

https://doi.org/10.15419/bmrat.v5i10.490

\section{Check for updates}

\section{Copyright}

( ) Biomedpress. This is an openaccess article distributed under the terms of the Creative Commons Attribution 4.0 International license.

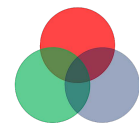

\begin{abstract}
Introduction: Treatment of cardiovascular risk factors seems to be necessary and involves a number of changes in drug treatment and lifestyle. This study aimed to evaluate the effects of Matricaria chamomilla L. hydroalcoholic extract on antioxidant activity, atherosclerotic plaques, lipid profile and inflammatory indicators in rats. Methods: Thirty male Wistar rats were divided into five experimental groups consisting of group 1 (Sham; normal dietary), group 2 (control; high cholesterol diet (2\%)), group 3 (high cholesterol diet plus $55 \mathrm{mg} / \mathrm{kg}$ of chamomile hydroalcoholic extract), group 4 (high cholesterol diet plus $110 \mathrm{mg} / \mathrm{kg}$ of chamomile hydroalcoholic extract), and group 5 (high cholesterol diet plus $10 \mathrm{mg} / \mathrm{kg}$ of lovastatin). At the beginning and end of the study, blood samples of all the animals were taken for determination of antioxidant activity and the level of biochemical parameters. The hearts and aorta were also isolated for ontological tests. Results: No symptom of plaque formation was observed in experimental groups 3,4 and 5 that received the high cholesterol diet. High cholesterol diet (2\%) resulted in a significant increase in serum cholesterol level, TG and LDL-c levels in groups 2 and 3 as compared to group $1(P<0.001)$. No significant difference was observed in serum cholesterol, TG and LDL-c levels in experimental groups 4 and 5, compared to experimental group 1. In group 4, serum HDL-c concentration did not show significant changes as compared to group 1. In groups 4 and 5, no significant change was observed in inflammatory factors as compared to group 1. The levels of superoxide dismutase in red blood cells and malondialdehyde in plasma of groups 3 and 5 showed no significant change when compared with group 1. Conclusion: Chamomile led to the management and correction of changes in risk factors of cardiovascular diseases.
\end{abstract}

Key words: Antioxidant activity, Atherosclerotic plaques, Inflammatory markers, Lipid profile, Matricaria chamomilla L., Rats

\section{INTRODUCTION}

Oxidative stress is one of the most important initiators of many diseases caused by free radicals ${ }^{1}$. Antioxidants are the most important defense mechanisms against free radicals ${ }^{2}$. Cardiovascular diseases (CVD) are known as the most prevalent cause of death worldwide and have become a major challenge for global health ${ }^{3,4}$. Coronary artery occlusion often begins with atherosclerosis; however, this phenomenon is associated with the deposition of cholesterol and calcium, or the production of cellular waste and other materials in the inner layers of the arteries, together with the formation of connective tissue, termed atherosclerosis plaques ${ }^{5-7}$.

The factors that increase the risk of atherosclerosis and cardiovascular diseases are divided into two groups: changeable and non-changeable. Changeable factors include high blood pressure, high blood sugar, physical activity and exercise. Non-changeable factors include age, sex, race and family history ${ }^{8,9}$. Lipids have been extensively studied due to their extensive association with atherogenesis, and the formation of atheroma plaques in the arteries as well as vascular stenosis ${ }^{10}$. Hyperlipidemia can increase the risk of cardiovascular diseases in the presence of other risk factors ${ }^{11}$. The main risk factors of atherosclerosis are disruption of normal activity of the vascular endothelium and also formation of atheroma plaques under the intima ${ }^{12}$.

Inflammation is developed via increase in oxidative stress which leads to plaque rupture and chronic deregulation ${ }^{5}$. Cholesterol-rich lipoproteins are stored in the vessel wall and induce inflammatory responses in the surrounding cells. However, arterial endothelial cells express leukocyte adhesion molecules as a part of this initial vascular re- 
sponse, which leads to the absorption of circulating monocytes and their differentiation into tissue macrophages ${ }^{13-15}$. Consequently, these macrophages absorb lipids and create foam cells in blood vessels, which play a very important role in the development and progression of atherosclerosis ${ }^{16}$.

It has been estimated that in the year 2020, cardiovascular diseases will account as the leading cause of death worldwide ${ }^{9}$. Therefore, control and treatment of the risk factors of these diseases seem necessary and should include a number of changes in lifestyle and drug treatments ${ }^{17}$.

The positive effect of a vegetarian diet has been demonstrated due to the presence of polyphenolic compounds and flavonoids ${ }^{18,19}$. Flavonoids are compounds that act against the disruptive effects of reactive oxygen species (ROS), such as superoxide radicals, and also protect the cells due to their antioxidant activity ${ }^{19}$. On the other hand, some plants also contain anti-inflammatory compounds that can be used to treat inflammation ${ }^{20}$. Long-term application of chemical drugs in order to inhibit inflammatory reactions results in complications, such as gastric and intestinal ulcers and subsequently anemia ${ }^{21}$. Hence, identification of herbal compounds with antiinflammatory properties has increased to try to circumvent the unwanted side effects of chemical drugs. Matricaria chamomilla L. (i.e. chamomile) is one of the herbs containing flavonoid compounds ${ }^{22}$. It is one of the oldest known herbs of traditional medicine that belongs to the Asteraceae family ${ }^{23}$. The main and active chemical elements in chamomile flowers include mainly flavonoids (e.g. Apigenin, Luteolin, and Quercetin), Terpenoid $\alpha$-Bisabolol, and its oxides (e.g. Chamazulene) ${ }^{24,25}$. Chamomile is used for pain relief, skin disease treatment (psoriasis, eczema, etc.), bronchitis and cold treatment, cough, fever, wound healing and gastrointestinal disease treatment in traditional medicine ${ }^{26-28}$. Apigenin in chamomile has anti-anxiety effects ${ }^{29}$.

Since cardiovascular diseases are the leading cause of mortality in the world, evaluation and identification of the factors affecting the reduction of the level of inflammatory parameters and increase in antioxidant activity are important for prevention and amelioration of these diseases. Accordingly, the main strategy is to increase the life expectancy and improve the health of individuals and communities. Hence, this study was carried out to investigate the effects of $M$. chamomilla hydroalcoholic extract on various inflammatory and coagulation parameters, lipid profile, atherosclerotic plaques, and antioxidant activity in hypercholesterolemic rats.

\section{METHODS}

The present study is an interventional in vitro study conducted at Ilam University of Medical Sciences (Iran). The stages were as follows:

\section{Extraction}

Matricaria chamomilla L. was obtained from the plains around the city of Ilam in springtime, then dried and powdered by electric grinders after identification and approval of their scientific name. The obtained powder was mixed with a hydroalcoholic solvent ( $80 \%$ ethanol and $20 \%$ distilled water) and placed in an incubator shaker $\left(34^{\circ} \mathrm{C}\right.$ and $\left.140 \mathrm{rpm}\right)$ for 3 days. The extract was then purified by Whatman filter paper and concentrated on a rotary. The dried extract was obtained by placing the concentrated extract in dry heat at $30-40^{\circ} \mathrm{C}$. It was then stored in the refrigerator for subsequent use.

\section{Determination of Toxicity ( $\left.\mathbf{L D}_{50}\right)$}

In order to determine the lethal dose of $M$. chamomile hydroalcoholic extract (MCHAE), 50 to $6400 \mathrm{mg} / \mathrm{kg}$ (expanded dosage increase) were injected intraperitoneally into 8 groups of animals. After $24 \mathrm{~h}$, the mortality rates of each group was measured. $\mathrm{LD}_{50}$ was calculated $(220 \mathrm{mg} / \mathrm{kg})$ using computer techniques, and 55 and $110 \mathrm{mg} / \mathrm{kg}$ hydroalcoholic extract of chamomile ( 25 and $50 \% \mathrm{LD}_{50}$ ) were used in this study.

\section{Grouping and treatment}

For this experimental study, 30 male mature Wistar rats weighing 150-180 g were used. Animals were purchased from the Animal Breeding Center of the Pasteur Institute of Tehran and transferred to the Animal Maintenance Center of Ilam University of Medical Sciences. They were kept in special cages (temperature of $25 \pm 2{ }^{\circ} \mathrm{C}$ and with 12 -h light cycles). Urban water and compressed foods were provided without any limitations. In order to adapt to the laboratory environment, animals were placed in these conditions 1 week before the study.

Group 1 or sham group received a regular daily diet and $2 \mathrm{cc}$ normal saline per day. Group 2 (i.e. control group) received a high cholesterol diet (2\%) and also 2 cc normal saline per day. Groups 3 and 4 were treated with a high cholesterol diet (2\%) together with 55 and $110 \mathrm{mg} / \mathrm{kg}$ of MCHAE, respectively. Finally, Group 5 received a high-cholesterol diet (2\%) plus $10 \mathrm{mg} / \mathrm{kg}$ of lovastatin (OSVAH Pharm. Co., Tehran, Iran). 


\section{Biochemical factors and their measure- ments}

Animals were put on fasting state for $12 \mathrm{~h}$ before the beginning of the diet and after completion of the study. Blood samples were collected twice- once at the beginning of the experiment and once at the end of the experiment. On the last day of the 8th week, and before each blood sampling, animals were kept at a fasting state for $12 \mathrm{~h}$. The blood was placed in the laboratory for half an hour to form a clot; then, tubes containing the clot were put in a centrifuge device and centrifuged for $5 \mathrm{~min}$ at $4500 \mathrm{rpm}$ to separate the serum. Finally, a biochemical kit was used to determine the concentration of malondialdehyde (MDA), superoxide dismutase (SOD), red blood cell (RBC) count, levels of inflammatory markers (e.g. Interleukin (IL)-6), C-reactive protein (CRP), tumor necrosis factor alpha (TNF- $\alpha$ ), and fibrinogen), and lipid profile. ELISA was used to measure MDA, SOD, IL-6, CRP, and fibrinogen using kits (ZellBio GmbH, Ulm, Germany). TNF- $\alpha$ was measured using Diaclone kit (Besancon, France). Lipid profile was also measured using a Biochemistry Enzymatic Kit (Pars Azmun Co., Tehran, Iran) and Hitachi's Automatic Analyzer 902 (Hitachi, Ltd. Tokyo, Japan).

The catalog numbers of the kits used in the experiments were:

MDA Cat. No: ZB-MDA96A, V405

SOD Cat. No: ZB-SOD96A, V407

IL-6 Cat. No: ZB-10135S-R9648

CRP Cat. No: ZB-10167-R9648

Fibrinogen Cat. No: ZB-12006S-H9648

TNF- $\alpha$ Cat. No: 1 x96 tests: 865.000 .096

HDL-c Cat. No: 1050012

LDL-c Cat. No: 123051 H912

Cholesterol Cat. No: 1500010

TG Cat. No: 1006132

After blood sampling at the end of the $8^{\text {th }}$ week, the heart and aorta of each rat were isolated and placed in $10 \%$ formalin solution for staining with hematoxylin and eosin ( $\mathrm{H} \& \mathrm{E})$, according to the ethical guidelines of working with laboratory animals and using sterile cuts. After staining, tissue slides were prepared and examined histologically by optical microscopy.

\section{Statistical analysis}

SPSS 16 software and one-way ANOVA were used to analyze the results. The mean level of variables were calculated as mean \pm SD for each group of rats. The statistical significance level for all the tests was set as $\mathrm{P}<0.05$.

\section{RESULTS}

\section{Weight}

The results of this study showed that at the end of the $1^{\text {st }}$ and $2^{\text {nd }}$ week, the groups had no significant differences in terms of mean weight. At the end of the $4^{\text {th }}$ week, the mean weight of animals in group 2 (control) showed a significant increase compared to group 1 (sham) $(\mathrm{P}<0.01)$. At the end of the $6^{\text {th }}$ week, as observed, groups 3 (55 mg/kg dose of MCHAE) and 2 (control) had a significant increase in weight gain, as compared to group $1(\mathrm{P}<0.01)$. At the end of the study ( $8^{\text {th }}$ week), similar to the $6^{\text {th }}$ week, there was a significant increase in these two groups as compared to group $1(\mathrm{P}<0.001$ and $\mathrm{P}<0.01$, respectively) (Figure 1).

\section{Atherosclerotic plaques}

The results of this study showed that atherogenic lesions and the symptoms of atheroma plaque formation were observed in group 2 (control, Figure 2B) which received the hypercholesterolemic diet (2\%). However, formation of plaques and its symptoms were not observed in group 1 (sham, Figure 2A) with normal diet. In groups 3 (Figure 2C) and 4 (Figure 2D) that received high cholesterol diet and MCHAE with the doses of 55 and $110 \mathrm{mg} / \mathrm{kg}$ body weight per day, as well as group 5 that received lovastatin at a dose of $10 \mathrm{mg} / \mathrm{kg}$ body weight per day in addition to the high cholesterol diet (Figure 2E), there were no signs nor symptoms of plaque formation (Figure 2).

Several slides were prepared from coronary artery, but symptoms of plaque formation were not observed in any of the groups.

\section{Lipid profile}

The results of this study showed that high cholesterol diet (2\%) significantly increased the level of serum cholesterol, TG and LDL-c in group 2 (control) as compared to group 1 (sham) $(\mathrm{P}<0.001)$. This significant increase $(\mathrm{P}<0.001)$ was also observed in group 3 ( $55 \mathrm{mg} / \mathrm{kg}$ dose of MCHAE) as compared to group 1. However, groups 4 and 5 had no significant change in serum cholesterol, TG or LDL-c levels in comparison with group 1 (normal diet) (Table 1).

Serum concentration of HDL-c showed a significant decrease in group 1 (sham) as compared to group 2 (control), group 3 and group $5(\mathrm{P}<0.001)$. However, group 4 showed no significant change in serum HDLc level as compared to group 1 (sham), despite the high cholesterol diet (Table 1). 


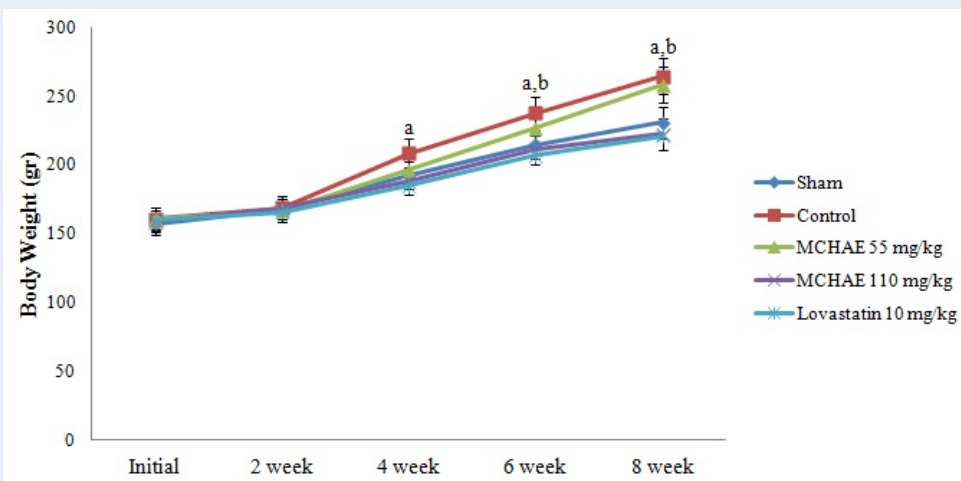

Figure 1: Comparison of the weight means of different groups during the 8 weeks. "a": experimental group 2 as compared to sham group, "b": experimental group 3 as compared to sham group). The mean difference was deemed significant at the 0.05 level (*: $P<0.05)$.

Table 1: Serum concentration of lipids in the various groups compared with group 1 (sham)

\begin{tabular}{|c|c|c|c|c|c|c|}
\hline $\begin{array}{l}\text { Lipid } \\
\text { profile }\end{array}$ & $\begin{array}{l}\text { Exp. Group } 1 \\
\text { (Sham) } \\
(\mathrm{mg} / \mathrm{dl})\end{array}$ & $\begin{array}{c}\text { Exp. Group } 2 \\
\text { (Control) }\end{array}$ & $\begin{array}{c}\text { Exp. Group } 3 \\
\text { (MCHAE } 55 \\
\text { mg/kg) }\end{array}$ & $\begin{array}{l}\text { Exp. Group } \\
4 \\
(\mathrm{MCHAE} \\
110 \mathrm{mg} / \mathrm{kg})\end{array}$ & $\begin{array}{c}\text { Exp. Group } 5 \\
\text { (Lovastatin } 10 \\
\text { mg/kg) }\end{array}$ & $\begin{array}{l}\text { P-value } \\
{ }^{*}: \mathrm{P}<0.05\end{array}$ \\
\hline Cholesterol & $84.81 \pm 5.26$ & $\underset{* * \star}{141.78 \pm 6.76}$ & $\underset{* * *}{133.08} \pm 4.22$ & $88.98 \pm 5.07$ & $84.33 \pm 5.92$ & $\begin{array}{l}\text { vs. Exp. } \\
\text { Group } 1 \\
\text { (Sham) }\end{array}$ \\
\hline TG & $71.23 \pm 4.22$ & $\underset{* * \star}{107.85} \pm 5.65$ & $\underset{* * \star}{102.95} \pm 3.54$ & $71.41 \pm 4.07$ & $70.61 \pm 6.00$ & $\begin{array}{l}\text { vs. Exp. } \\
\text { Group } 1 \\
\text { (Sham) }\end{array}$ \\
\hline LDL-c & $46.40 \pm 2.59$ & $\underset{* \star *}{63.31 \pm 4.91}$ & $\underset{* \star *}{59.56 \pm 3.79}$ & $46.90 \pm 4.30$ & $49.93 \pm 4.26$ & $\begin{array}{l}\text { vs. Exp. } \\
\text { Group } 1 \\
\text { (Sham) }\end{array}$ \\
\hline HDL-c & $34.80 \pm 1.85$ & $\underset{* \star *}{21.55} \pm 1.57$ & $\underset{* \star *}{23.61 \pm 1.60}$ & $32.90 \pm 2.15$ & $\underset{* * *}{25.35} \pm 1.88$ & $\begin{array}{l}\text { vs. Exp. } \\
\text { Group } 1 \\
\text { (Sham) }\end{array}$ \\
\hline
\end{tabular}

The mean difference was deemed significant at the 0.05 level $\left({ }^{*}: \mathrm{P}<0.05\right)$

\section{Inflammatory Indicators}

At the end of the study, a comparison of the mean inflammatory factors shows that for groups 4 and 5, no statistical significant difference was observed when compared to group 1 (sham), which received only the usual diet $(\mathrm{P}>0.05)$. However, in groups 2 (control) and 3, all inflammatory factors increased significantly as compared to group $1(\mathrm{P}<0.001$ and $\mathrm{P}<0.05$, respectively) (Table 2).

\section{Antioxidant activity}

The level of SOD of RBCs in groups 2 (control) and 4 showed a significant increase when compared to that of group 1 (sham) $(\mathrm{P}<0.001$ and $\mathrm{P}<0.05$, respectively). However, in groups 3 and 5, a significant increase in RBC SOD rate was observed in comparison with the sham group, despite receiving a cholesterol-rich diet (Figure 3).

Furthermore, plasma MDA levels of groups 2 (control) and 4 had a significant increase in comparison with group 1 (sham) $(\mathrm{P}<0.01$ and $\mathrm{P}<0.05$, respectively). However, no significant change was observed 

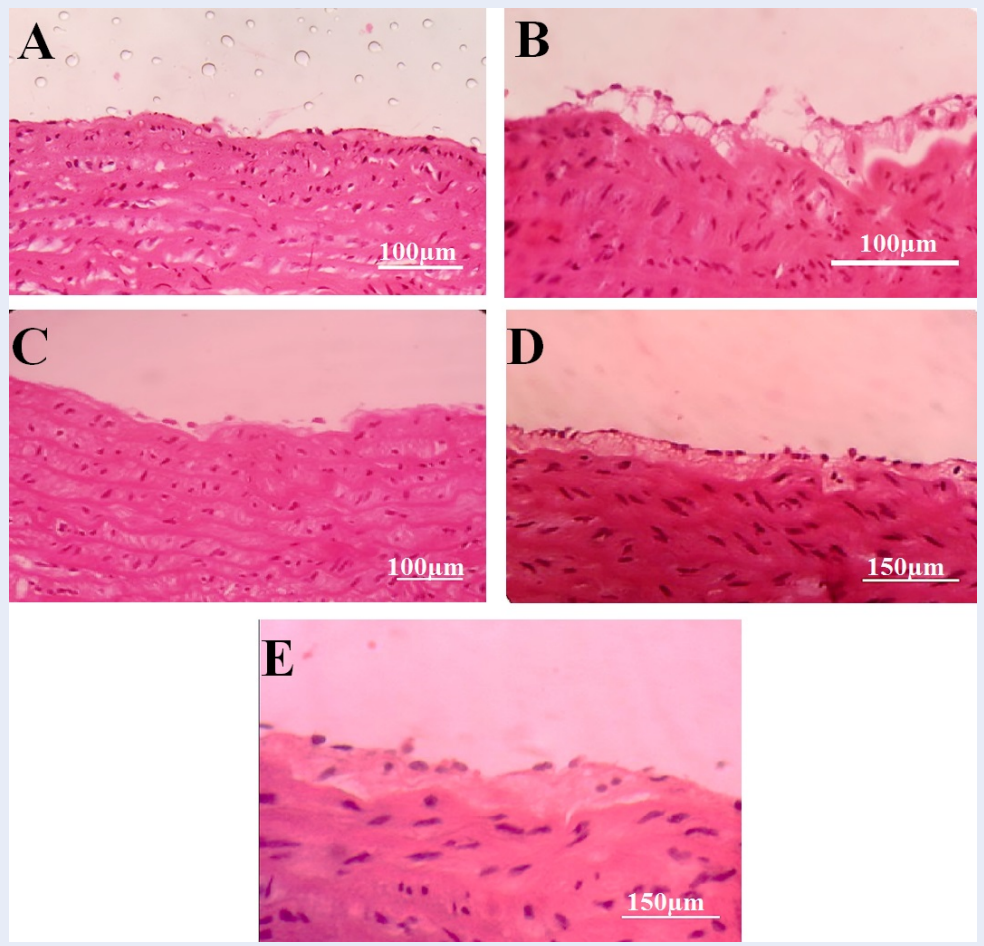

Figure 2: Histological observations of the aorta section (Staining of hematoxylin and eosin, magnification of $40 \times$ ). A: Experimental group 1 (Sham); B: Experimental group 2 (Control); C: Experimental group 3; D: Experimental group 4; E: Experimental group 5.

Table 2: Serum concentration of Inflammatory Indicators in the various groups compared with group 1 (sham)

\begin{tabular}{|c|c|c|c|c|c|c|}
\hline $\begin{array}{l}\text { Inflammatory } \\
\text { factors }\end{array}$ & $\begin{array}{c}\text { Exp. Group } 1 \\
\text { (Sham) }\end{array}$ & $\begin{array}{l}\text { Exp. Group } \\
2 \text { (Control) }\end{array}$ & $\begin{array}{l}\text { Exp. Group } \\
\quad 3 \\
\text { (MCHAE } 55 \\
\text { mg/kg) }\end{array}$ & $\begin{array}{c}\text { Exp. Group } \\
4 \\
(\mathrm{MCHAE} \\
110 \mathrm{mg} / \mathrm{kg})\end{array}$ & $\begin{array}{l}\text { Exp. Group } \\
5 \\
\text { (Lovastatin } \\
10 \mathrm{mg} / \mathrm{kg} \text { ) }\end{array}$ & $\begin{array}{l}\text { P-value } \\
{ }^{*}: \mathbf{P}<0.05\end{array}$ \\
\hline Fibrinogen & $\begin{array}{c}2.27 \pm 0.07 \\
(\mathrm{mg} / \mathrm{mL})\end{array}$ & $\begin{array}{c}3.70 \pm 0.08 \\
\star * \star\end{array}$ & $\begin{array}{c}2.68 \pm \\
\pm \\
*\end{array}$ & $2.33 \pm 0.07$ & $2.41 \pm 0.10$ & $\begin{array}{c}\text { vs. Exp. Group } \\
1 \text { (Sham) }\end{array}$ \\
\hline TNF- $\alpha$ & $\begin{array}{c}10.97 \pm 0.21 \\
(\mathrm{pg} / \mathrm{mL})\end{array}$ & $\underset{* * *}{17.81 \pm 0.30}$ & $\begin{array}{c}13.06 \pm 0.14 \\
*\end{array}$ & $11.32 \pm 0.25$ & $11.19 \pm 0.15$ & $\begin{array}{l}\text { vs. Exp. Group } \\
1 \text { (Sham) }\end{array}$ \\
\hline CRP & $\begin{array}{c}1.92 \pm 0.07 \\
(\mathrm{ng} / \mathrm{mL})\end{array}$ & $\begin{array}{c}3.18 \pm 0.19 \\
* * *\end{array}$ & $\begin{array}{c}2.32 \pm 0.07 \\
*\end{array}$ & $2.01 \pm 0.10$ & $1.98 \pm 0.12$ & $\begin{array}{c}\text { vs. Exp. Group } \\
1 \text { (Sham) }\end{array}$ \\
\hline IL6 & $\begin{array}{c}2.95 \pm 0.04 \\
(\mathrm{ng} / \mathrm{L})\end{array}$ & $\underset{* * \star}{3.78} \pm 0.09$ & $\begin{array}{c}3.38 \pm 0.14 \\
*\end{array}$ & $3.10 \pm 0.06$ & $3.06 \pm 0.09$ & $\begin{array}{c}\text { vs. Exp. Group } \\
1 \text { (Sham) }\end{array}$ \\
\hline
\end{tabular}




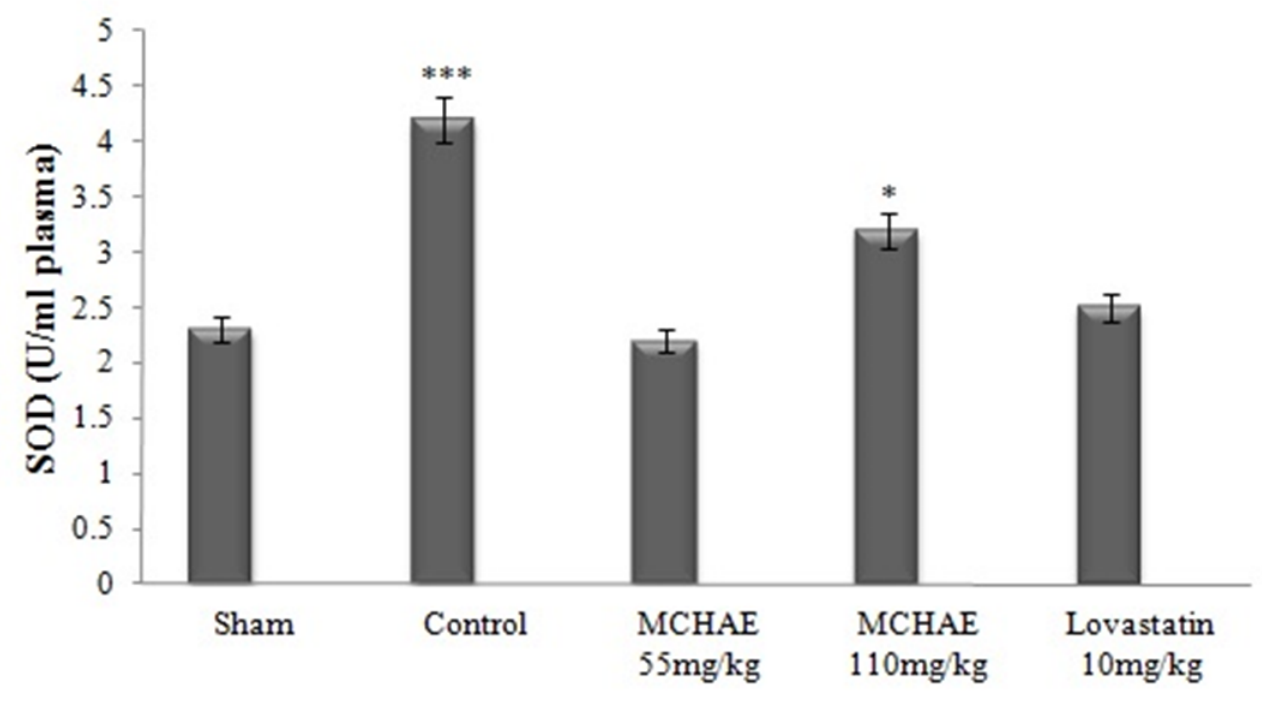

Figure 3: Comparison of SOD of RBC in the various groups with that of group 1 (sham). The mean difference was deemed significant at the 0.05 level $\left({ }^{*}: \mathrm{P}<0.05\right)$.

in groups 3 and 5 as compared to the sham group (Figure 4).

\section{DISCUSSION}

As mentioned earlier, hyperlipidemia is known as a major risk factor for cardiovascular diseases, especially atherosclerosis ${ }^{10}$. Therefore, controlling and correcting changes in lipid profiles can play a significant important role in reducing cardiovascular diseases. For this purpose, in a part of this study, the effects of $M$. chamomile hydroalcoholic extract on the level of inflammatory indicators and lipid profiles were studied.

In this study, administration of MCHAE caused a significant decrease in serum levels of triglyceride, cholesterol and LDL-c, and caused a significant increase in serum HDL-c levels in treated rats as compared to the control group. Interestingly, $110 \mathrm{mg} / \mathrm{kg}$ of chamomile extract resulted in a more significant increase in HDL-c levels than lovastatin, with a dose of $10 \mathrm{mg} / \mathrm{kg}$ as compared to the control group. The positive effects of MCHAE on lipid profile in this study are consistent with previous studies. For example, in a study conducted by Khan et al. on rats that received high cholesterol diet, it was found that phenolic compounds inhibited the activity of HM-COA reductase and reduced the storage of liver cholesterol ${ }^{30}$.

One of the most important disruptive effects of free radicals is the beginning of lipid peroxidation, which leads to destruction of the cell membrane ${ }^{31}$. Lipid peroxidation results in changes in the membrane organization and changes in the activity of its dependent enzymes and other proteins. These events are potentially toxic to the cell, together with the release of hydroperoxyl radicals and alkoperoxyls ${ }^{32}$. Reestablishing the equilibrium between pro-oxidants and antioxidants allows the cell to regain its physiological activity ${ }^{33}$. Free radicals and ROS cause damage to cells and tissues, and promote the development of various diseases, such as cardiovascular diseases, atherosclerosis, cancer, rheumatoid arthritis, and even early aging. Given the fact that these compounds are continuously produced in living cells, there is a need for protective mechanisms against them ${ }^{34}$. In hyperlipidemic patients, the levels of lipid peroxidation and LDL oxidation increased, and as a result, the need for antioxidants increased ${ }^{35}$.

Antioxidants are effective in the improvement of cardiac lesions, infarction and cardiac arrhythmias by reducing the effect of free radicals and coronary artery thrombosis ${ }^{36}$. Natural antioxidants with plant origin, especially oral herbs, in addition to having fewer side effects than chemical antioxidants, can help in protecting the body against free radicals.

The results of this study showed that chamomile hydroalcoholic extract has suitable antioxidant effects and due to the different effects of doses used in this study, it seems that this effect is not dose-dependent. Thus, $55 \mathrm{mg} / \mathrm{kg}$ chamomile extract with higher antibiotic effect as compared to $110 \mathrm{mg} / \mathrm{kg}$, prevented an increase in plasma MDA and SOD globules. The results 


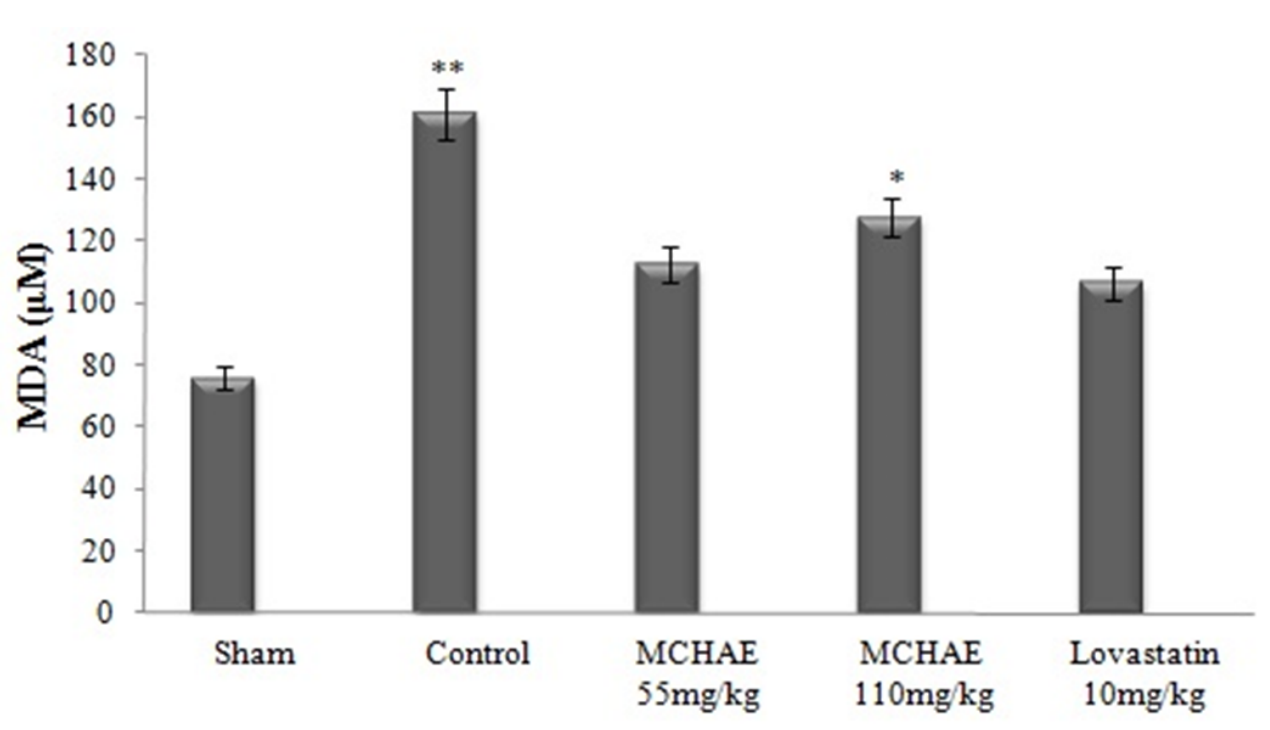

Figure 4: Comparison of Plasma MDA of the various groups with that of group 1 (sham). The mean difference was deemed significant at the 0.05 level $(*: P<0.05)$.

of antioxidant activity of chamomile extract in this study are consistent with those of Ranjbar et al. that studied the protective effect of chamomile hydroalcoholic extract on paraquat toxicity in male rats ${ }^{37}$.

Hypolipidemic compounds and antioxidants prevent atherosclerosis. Studies have shown that increased lipid oxidation leads to normal vascular endothelial dysfunction and atheroma plaque formation ${ }^{12}$. Lipid peroxidation results in the production of a wide range of substances, such as free oxygen radicals, ketones, ethers, aldehydes and foam cells, which in turn, interfere with endothelial cell attachment and plate formation $^{38}$. In a study conducted by Asghari et al., the use of chamomile extract resulted in a significant increase in the activity of antioxidant indicators in rat liver cells exposed to oxidant compound ${ }^{1}$. Therefore, it seems that the hydroalcoholic extract of chamomile can play a strong protective role in the prevention of cardiovascular disease because it contains flavonoids and polyphenolic, and reduces lipid peroxidation and substrates of antioxidant enzymes, such as superoxide dismutase and malondialdehyde.

In this study, the effects of chamomile extract on the level of blood inflammatory indicators were investigated. When cardiovascular diseases (including coronary artery sclerosis) develop, blood inflammatory indicators such as TNF- $\alpha$, CRP, IL- $\beta 1$, and IL- 6 are altered $^{39,40}$. The level of these indices increases as a result of inflammation which is caused by increased oxidative stress ${ }^{41}$. The results of this study indicate that treatment with $110 \mathrm{mg} / \mathrm{kg}$ chamomile hydroalcoholic extract prevents a significant increase in serum levels of TNF- $\alpha$, CRP, IL- 6 and Fibrinogen, as compared to group 1 (sham). These results are consistent with previous studies that emphasized the anti-oxidant and anti-inflammatory properties of chamomile ${ }^{1,42}$. In a study which was conducted to evaluate the effects of chamomile capitulum on xylene-acetic acid-induced inflammation in rats, it was observed that the herb had an anti-inflammatory effect ${ }^{42}$.

Chamomile extract consists of 120 types of chemical compounds, with the most important ones being chamazulenes, flavonoids and coumarins ${ }^{36,43}$. It seems that chamomile has antioxidant properties and the ability to neutralize oxygen radicals due to the presence of flavonoid compounds ${ }^{43,44}$. The association of terpenoids in plants with strong anti-inflammatory effects has also been proven ${ }^{45}$. Flavonoids are also responsible for lowering of blood pressure and anti-inflammatory properties ${ }^{46}$. It is evident that the most common intervention in the prevention of cardiovascular diseases is the use of drugs which lower blood lipids- that is, statins ${ }^{47}$. The use of statins causes reduction in serum LDL level, coronary artery diseases and finally reduction in mortality rates ${ }^{47,48}$. But, this set of drugs is known to have many side effects like myopathy, rhabdomyolysis, reduction in hepatic enzymes, nausea, dizziness and digestive tract problems, as well as elevation in cancer risk, 
liver damage and an increased risk of new-onset diabetes mellitus ${ }^{49-53}$. Life-threatening rhabdomyolysis and idiopathic polyneuropathy represent the most important muscular symptoms ${ }^{54-60}$. Both conditions are among the inherent properties of statins ${ }^{55,58-60}$. Statins have also been reported to inhibit the biosynthesis of Q10 coenzyme which is required for energy generation ${ }^{61,62}$. Due to the same reasons, the use of statins is accompanied by clinical constraints. Therefore, the hydroalcoholic extract of chamomile is suitable for reducing the level of inflammatory indicators, correction of lipid profile changes and prevention of cardiovascular diseases, including atherosclerotic plaques in animal samples.

\section{CONCLUSIONS}

The results of this study revealed that treatment of hypercholesterolemic rats with chamomile hydroalcoholic extract did not only prevent a significant increase of triglycerides, cholesterol and LDL-c levels and inflammatory factors, but it also prevented significant reduction in serum HDL-c levels. However, the suitable dose in this study was $110 \mathrm{mg} / \mathrm{kg}$ chamomile hydroalcoholic extract except for the antioxidant activity part. This extract also prevented the development of atheroma plaques in hypercholesterolemic rats. As mentioned earlier, these effects are probably due to the presence of flavonoids in the chamomile. In general, people at risk of cardiovascular diseases are recommended to strengthen their antioxidant potency with the use of natural antioxidants to minimize the risk of free radicals. Of course, understanding the exact mechanism of these reagents requires precise molecular and mechanistic studies in the future.

\section{COMPETING INTERESTS}

The authors report no conflicts of interest in this work.

\section{AUTHORS' CONTRIBUTIONS}

Shahin Nargesi, Ardeshir Moayeri, Ayub Ghorbani and Mansour Amraei designed the study and performed the experiments, Ehsan Shirzadpour conducted the data analysis, Mansour Amraei, Ehsan Shirzadpour and Yaser Seifinejad participated in drafting the paper, Shahin Nargesi, Ardeshir Moayeri and Mansour Amraei wrote the manuscript. All authors read and approved the manuscript.

\section{ACKNOWLEDGMENTS}

The authors thank the Deputy Director of Research and Technology, Ilam University of Medical Sciences.

\section{ETHICAL APPROVAL}

This study was carried out in accordance with the recommendations of ICLAS (International Council for Laboratory Animal Science). The protocol was approved by the Ethics committee of Ilam University of Medical Sciences (IR.MEDILAM.REC.1394.162).

\section{ABBREVIATIONS}

CRP: C-reactive protein

CVD: Cardiovascular diseases

HDL-c:High-density lipoprotein cholesterol

IL-6: Interleukin 6

IL- $\beta$ 1: Interleukin $\beta 1$

LDL-c:Low-density lipoprotein cholesterol

MCHAE: Matricaria chamomile hydroalcoholic extract

MDA: Malondialdehyde

ROS: Reactive oxygen species

SOD: Superoxide dismutase

TG:Triglycerides

TNF- $\alpha$ : Tumor necrosis factor

\section{REFERENCES}

1. Asghari S, Naderi GH, Bashardoost N, Etminan Z. The study of antioxidant potential of chamaemelum nobile extract on liver cell of rats. Journal of Herbal Drugs. 2011;1:69-76.

2. Köksal E, Ilhami Gülçin. Antioxidant activity of cauliflower (Brassica oleracea L.). Turkish Journal of Agriculture and Forestry. 2008;32:65-78.

3. Kochanek KD HMMS Xu J. Deaths: Final Data for 2012. Natl Vital Stat Rep. 2015;63:1-117.

4. Benjamin EJ, Blaha MJ, Chiuve SE, Cushman M, Das SR, Deo $\mathrm{R}$, et al. Heart disease and stroke statistics-2017 update: a report from the American Heart Association. Circulation. 2017;135:e146-603. Available from: Doi:10.1161/cir. 0000000000000485.

5. Pearson TA, Palaniappan LP, Artinian NT, Carnethon MR, Criqui MH, Daniels SR, et al. American Heart Association Guide for Improving Cardiovascular Health at the Community Level, 2013 update: a scientific statement for public health practitioners, healthcare providers, and health policy makers. Circulation. 2013;127:1730-53. Available from: DOI:10.1161/CIR. 0b013e31828f8a94.

6. Reed J. Cranberry flavonoids, atherosclerosis and cardiovascular health. Critical Reviews in Food Science and Nutrition. 2002;42:301-16. Available from: Doi:10.1080/ 10408390209351919.

7. Mahmoudi M, Curzen N, Gallagher PJ. Atherogenesis: the role of inflammation and infection. Histopathology. 2007;50:53546. Available from: DOI:10.1111/j.1365-2559.2006.02503.x.

8. Cesare MD, Bentham J, Stevens GA, Zhou B, Danaei G, and YL. Trends in adult body-mass index in 200 countries from 1975 to 2014: a pooled analysis of 1698 populationbased measurement studies with 19.2 million participants. Lancet. 2016;387:1377-96. Available from: Doi:10.1016/ s0140-6736(16)30054-x.

9. Huffman MD, Capewell S, Ning H, Shay CM, Ford ES, LloydJones DM. Cardiovascular health behavior and health factor changes (1988-2008) and projections to 2020: results from the National Health and Nutrition Examination Surveys. Circulation. 2012;125:2595-602. Available from: Doi:10.1161/ circulationaha.111.070722. 
10. Krause MP, Hallage T, Gama MP, Sasaki JE, Miculis CP, Buzzachera CF. Association between lipid profile and adiposity in women over age 60. Arquivos Brasileiros de Cardiologia. 2007;89:147-53

11. Ahaneku JE, Nwosu CM, Farotimi A. Lipid and lipoprotein cardiovascular risk factorresponses to episodic academic stress. Journal of Health Science. 2001;47:323-6. Available from: DOI:10.1248/jhs.47.323.

12. $S A A E$, J L. Ischemic heart disease. In: FA LD, DL K, SL H, JL J, J $L$, editors. Harrison's Principles of Internal Medicine. New York: The McGraw-Hill Companies Inc; 2012. p. 1998-2015.

13. Pan LL, Qin M, Liu XH, Zhu YZ. The Role of Hydrogen Sulfide on Cardiovascular Homeostasis: An Overview with Update on Immunomodulation. Frontiers in Pharmacology. 2017;8:686. Available from: DOI:10.3389/fphar.2017.00686.

14. Libby P, Hansson GK. Inflammation and immunity in diseases of the arterial tree: players and layers. Circulation Research. 2015;116:307-11. Available from: Doi:10.1161/circresaha.116. 301313.

15. Kirbis S, Breskvar UD, Sabovic M, Zupan I, Sinkovic A. Inflammation markers in patients with coronary artery diseasecomparison of intracoronary and systemic levels. Wiener Klinische Wochenschrift. 2010;122:31-4. Available from: DOI: 10.1007/s00508-010-1343-z.

16. Moore KJ, Tabas I. Macrophages in the pathogenesis of atherosclerosis. Cell. 2011;145:341-55. Available from: DOI: 10.1016/j.cell.2011.04.005.

17. Mamedov MN. [Algorithm of diagnosis and treatment of metabolic syndrome]. Cardiología (Barcelona). 2005;45:92100.

18. Parfitt VJ, Rubba P, Bolton C, Marotta G, Hartog M, Mancini $M$. A comparison of antioxidant status and free radical peroxidation of plasma lipoproteins in healthy young persons from Naples and Bristol. European Heart Journal. 1994;15:8716. Available from: DOI:10.1093/oxfordjournals.eurheartj. a060603.

19. Morel I, Lescoat G, Cogrel P, Sergent O, Pasdeloup N, Brissot P. Antioxidant and iron-chelating activities of the flavonoids catechin, quercetin and diosmetin on iron-loaded rat hepatocyte cultures. Biochemical Pharmacology. 1993;45:13-9. Available from: Doi:10.1016/0006-2952(93)90371-3.

20. Anilkumar M. 10. Ethnomedicinal plants as anti-inflammatory and analgesic agents. Ethnomedicine: A source of complementary therapeutics. 2010;p. 267-293.

21. Palasuwan $A$, Soogarun $S$, Lertlum $T$, Pradniwat $P$, Wiwanitkit V. Inhibition of Heinz body induction in an in vitro model and total antioxidant activity of medicinal Thai plants. Asian Pacific Journal of Cancer Prevention. 2005;6:458-63.

22. Heidari M, Sarani S. Growth, biochemical components and ion content of Chamomile (Matricaria chamomilla L.) under salinity stress and iron deficiency. Journal of the Saudi Society of Agricultural Sciences. 2012;11:37-42. Available from: DOI:10.1016/j.jssas.2011.05.002.

23. Srivastava JK, Shankar E, Gupta S. Chamomile: A herbal medicine of the past with bright future. Molecular Medicine Reports. 2010;3:895-901.

24. Zick SM, Wright BD, Sen A, Arnedt JT. Preliminary examination of the efficacy and safety of a standardized chamomile extract for chronic primary insomnia: a randomized placebocontrolled pilot study. BMC complementary and alternative medicine. 2011;11:78.

25. Gardiner P. Chamomile (Matricaria recutita, Anthemis nobilis). Longwood Herbal Task Force. 1999;

26. Singh O, Khanam Z, Misra N, Srivastava MK. Chamomile (Matricaria chamomilla L.): an overview. Pharmacognosy Reviews. 2011;5:82-95. Available from: Doi:10.4103/0973-7847.79103.

27. Golparvar AR, Ghasemi-Pirbalouti A, Karimi M. Determination of the effective traits on essence percent and dry flower yield in German chamomile (Matricaria chamomilla L.) populations. Journal of Medicinal Plants Research. 2011;5:3242-6.

28. ni Wu Y, Xu Y, Yao L. Anti-inflammatory and anti-allergic effects of German chamomile (Matricaria chamomilla L.). Journal of
Essential Oil Bearing Plants. 2012;15:75-83.

29. Head KA, Kelly GS. Nutrients and botanicals for treatment of stress: adrenal fatigue, neurotransmitter imbalance, anxiety, and restless sleep. Alternative Medicine Review. 2009;14:11440.

30. Khan A, Safdar M, Khan MMA, Khattak KN, Anderson RA. Cinnamon improves glucose and lipids of people with type 2 diabetes. Diabetes Care. 2003;26:3215-8. Available from: DOI:10.2337/diacare.26.12.3215.

31. Haraguchi H, Saito T, Ishikawa H, Date H, Kataoka S, Tamura Y. Antiperoxidative components in Thymus vulgaris. Planta Medica. 1996;62:217-21. Available from: DOI:10.1055/s2006-957863.

32. Joyeux M, Rolland A, Fleurentin J, Mortier F, Dorfman P. tertButyl hydroperoxide-induced injury in isolated rat hepatocytes: a model for studying anti-hepatotoxic crude drugs. Planta Medica. 1990;56:171-4. Available from: DOI:10.1055/ s-2006-960918.

33. Leung FY. Trace element that act as antioxidants is parenteral micronutrition. The Journal of Nutritional Biochemistry. 1998;9:304-7. Available from: Doi:10.1016/s0955-2863(98) 00018-7.

34. Vzsioli F, Galli C. Evaluating oxidation processes in relation to cardiovascular disease. Acurrent review of oxidant antioxidant methodology. Nutrition, Metabolism, and Cardiovascular Diseases. 1997;7:459-66.

35. Clarke R, Armitage J. Antioxidant vitamins and risk of cardiovascular disease. Review of large-scale randomised trials. Cardiovascular Drugs and Therapy. 2002;16:411-5. Available from: Doi:10.1023/a:1022134418372.

36. Singh RB, Niaz MA, Rastogi SS, Rastogi S. Usefulness of antioxidant vitamins in suspected acute myocardial infarction (the Indian experiment of infarct survival-3). The American Journal of Cardiology. 1996;77:232-6. Available from: Doi: 10.1016/s0002-9149(97)89384-8.

37. Ranjbar A, Khajavi F, Hossini-Zijoud SM, Ghasemi H, Mohsenzadeh F, Chehregani A. Effects of hydroalcoholic extract Matricaria chamomilla L. on paraquat-induced blood oxidative toxicity in rat. Medicinal Plant. 2014;13:73-82.

38. Cushing SD, Berliner JA, Valente AJ, Territo MC, Navab $M_{\text {, }}$ Parhami F. Minimally modified low density lipoprotein in duces monocyte chemotactic protein 1 in human endothelial cells and smooth muscle cells. Proceedings of the $\mathrm{Na}$ tional Academy of Sciences of the United States of America. 1990;87:5134-8. Available from: DOI:10.1073/pnas.87.13. 5134 .

39. Baldassarre D, Porta B, Camera M, Amato M, Arquati M, and BB. Markers of inflammation, thrombosis and endothelial activation correlate with carotid IMT regression in stable coronary disease after atorvastatin treatment. Nutrition, Metabolism, and Cardiovascular Diseases. 2009;19:481-90. Available from: DOI:10.1016/j.numecd.2008.10.003.

40. Pearson TA, Mensah GA, Alexander RW, Anderson JL, Cannon $\mathrm{RO}$, Criqui $\mathrm{M}$, et al. Markers of inflammation and cardiovascular disease: application to clinical and public health practice: A statement for healthcare professionals from the Centers for Disease Control and Prevention and the American Heart Association. Circulation. 2003;107:499-511. Available from: Doi:10.1161/01.cir.0000052939.59093.45.

41. Bell HK, Bloomer RJ. Impact of serum estradiol on postprandial lipemia, oxidative stress, and inflammation across a single menstrual cycle. Gender Medicine. 2010;7:166-78. Available from: DOI:10.1016/j.genm.2010.03.001.

42. Amraei M, Bagrezaei F, Taghinejad H, Mohamadpour S. Hydroalcoholic Extract of Matricaria chamomilla effectively reduces inflammation induced by xylene in rat. Journal of Basic Research in Medical Sciences. 2015;2:36-30.

43. McKay DL, Blumberg JB. A review of the bioactivity and potential health benefits of chamomile tea (Matricaria recutita L.). Phytotherapy Research. 2006;20:519-30. Available from: DOI:10.1002/ptr.1900. 
44. Abdoul-Latif FM, Mohamed N, Edou P, Ali AA, Djama SO, Obame LC. Antimicrobial and antioxidant activities of essential oil and methanol extract of Matricaria chamomilla L. from Djibouti. Journal of Medicinal Plants Research. 2011;5:1512-7.

45. Govindappa M, Sadananda TS, Channabasava R, Raghavendra V. In vitro anti-inflammatory, lipoxygenase, xanthine oxidase and acetycholinesterase inhibitory activity of Tecoma Stans. International Journal of Pharma and Bio Sciences. 2011;2:27583.

46. Sathishkumar T, Baskar R, Shanmugam S, Rajasekaran P, Manikandan V. Optimization of flavonoids extraction from the leaves of Tabernaemontana heyneana wall using L16 orthogonal design. Nature and Science. 2008;6:10-21.

47. Mosca LJ. Optimal management of cholesterol levels and the prevention of coronary heart disease in women. American Family Physician. 2002;65:217-26.

48. Collins R, Armitage J, Parish S, Sleigh P, Peto R. Heart Protection Study Collaborative Group. MRC/BHF heart protection study of cholesterol-lowering with simvastatin in 5963 people with diabetes: a randomised placebocontrolled trial. Lancet. 2003;361:2005-16. Available from: Doi:10.1016/ s0140-6736(03)13636-7.

49. seid MT, Henriksen OA, Lindal S. Statin-associated myopathy with normal creatine kinase levels. Case report from a Norwegian family. APMIS. 2005;113:635-7. Available from: DOI:10.1111/j.1600-0463.2005.apm_270.x.

50. Gama MP, Pellegrinello S, Alonso SS, Coelho JF, Martins CF, Biagini GL. [High doses statins administration causing rhabdomyolysis: case report]. Arquivos Brasileiros de Endocrinologia \& Metabologia. 2005;49:604-9. Available from: Doi:10. 1590/s0004-27302005000400021.

51. Purvin V, Kawasaki A, Smith KH, Kesler A. Statin-associated myasthenia gravis: report of 4 cases and review of the literature. Medicine. 2006;85:82-5. Available from: DOI:10.1097/ 01.md.0000209337.59874.aa.

52. Alsheikh-Ali AA, Trikalinos TA, Kent DM, Karas RH. Statins, lowdensity lipoprotein cholesterol, and risk of cancer. Journal of the American College of Cardiology. 2008;52:1141-7. Available from: DOI:10.1016/j.jacc.2008.06.037.

53. Li H, Lin $\mathrm{H}$, Zhao $H, X u Y$, Cheng $Y$, Shen $P$. Statins use and risk of new-onset diabetes in hypertensive patients: a populationbased retrospective cohort study in Yinzhou district, Ningbo city, People's Republic of China. Therapeutics and Clinical Risk Management. 2018;14:823-32. Available from: Doi:10.2147/ tcrm.s158850.

54. Phan T, McLeod JG, Pollard JD, Peiris O, Rohan A, Halpern JP. Peripheral neuropathy associated with simvastatin. Journa of Neurology, Neurosurgery, and Psychiatry. 1995;58:625-8. Available from: DOI:10.1136/jnnp.58.5.625.

55. Jeppesen U, Gaist D, Smith T, Sindrup SH. Statins and peripheral neuropathy. European Journal of Clinical Pharmacology. 1999;54:835-8. Available from: DOI:10.1007/s002280050562.

56. Gaist D, Jeppesen U, Andersen M, Rodríguez LAG, Hallas J, Sindrup $\mathrm{SH}$. Statins and risk of polyneuropathy: a case-control study. Neurology. 2002;58:1333-7. Available from: Doi:10. 1212/wnl.58.9.1333.

57. Hodel C. Myopathy and rhabdomyolysis with lipid-lowering drugs. Toxicology Letters. 2002;128:159-68. Available from: Doi:10.1016/s0378-4274(02)00010-3.

58. Omar MA, Wilson JP. FDA adverse event reports on statinassociated rhabdomyolysis. The Annals of Pharmacotherapy. 2002:36:288-95. Available from: DOI:10.1345/aph.1A289.

59. Sinzinger $H$, Wolfram R, Peskar BA. Muscular side effects of statins. Journal of Cardiovascular Pharmacology. 2002;40:163-71. Available from: Doi:10.1097/00005344200208000-00001.

60. Thompson PD, Clarkson P, Karas RH. Statin-associated myopathy. Journal of the American Medical Association. 2003;289:1681-90. Available from: DOI:10.1001/jama.289.13. 1681.

61. Ghirlanda G, Oradei A, Manto A, Lippa S, Uccioli L, Caputo S. Evidence of plasma CoQ10-lowering effect by HMG-CoA reductase inhibitors: a double-blind, placebo-controlled study. Journal of Clinical Pharmacology. 1993;33:226-9. Available from: DOI:10.1002/j.1552-4604.1993.tb03948.x.

62. Folkers $\mathrm{K}$, Vadhanavikit $\mathrm{S}$, Mortensen SA. Biochemical rationale and myocardial tissue data on the effective therapy of cardiomyopathy with coenzyme Q10. Proceedings of the National Academy of Sciences of the United States of America. 1985;82:901-4. Available from: DOI:10.1073/pnas.82.3.901. 